DOI https://doi.org/10.36059/978-966-397-108-7/21-40

\title{
FUNCTIONAL DIFFERENTIATION OF EARLY MODERN EUROPEAN SOCIETY AND THE PRESENT TIME
}

\author{
Kosmyna V. G.
}

\section{INTRODUCTION}

The modern conditions and prospects of human society, first of all, in the field of interdependence and rather complex interaction of civilizations, can not be clarified without understanding of origins and meaning of differences in the system structure of the society within each civilization. Such understanding becomes possible by using the systematic theory of one of the most prominent sociologist of the late $20^{\text {th }}$ century Niklas Luhmann.

Firstly, there are some remarks concerning this sociological theory itself. German scientist described its different aspects in dozens of his comprehensive works. "The Social Systems" (1984) ${ }^{1}$ and "Society of the Society" are the most well-known and generalized among them. Originality, if not unusualness of the theory, is associated with the fact that the society is considered as a system constructed on communications between people in it alone. The people themselves, as consciousness systems, or psychological systems are in the environment of the system. They make communications possible, but they are not their part, thus, they are not the part of the society as well. Communications have only meaningful relation between each other.

Every individual communicative operation consists of three elements: the addresser's message, the information contained in the message, understanding of the message (extracting personal information from the message) by the addressee. Understanding is the most essential element here since both the nature and the meaning of further communication operations depend on it, namely, continuation (or cessation) of communications as well as their inclusion in one or another consciousness system (or subsystem). In the terms of historical process and its studying

\footnotetext{
${ }^{1}$ Luhmann N. Soziale Systeme. Grundriss einer allgemeinen Theorie /Niklas Luhmann. Frankfurt am Main : Suhrkamp Verlag, 1984. 674 S.

${ }^{2}$ Luhmann N. Die Gesellschaft der Gesellschaft / Niklas Luhmann. Frankfurt am Main: Suhrkamp Verlag, 1997. 1150 S.
} 
by historians it turns out that every action or event, any historical source is nothing else but communication. The main thing is that they have to reveal themselves outside and other participants as well as contemporaries understand them and continue communication in one or another way.

It is through meaningful relation that communications are constructed in both meaningful sequences and entire social systems where they are united by joint meaningful codes. This connection can be internal (consecutive) in each subsystem or external (reactive), interacting between subsystems, when each of them reacts by own changes to the processes in its environment. All that is "left" for a historian is to observe the meaningful relations of communications by their "imprints" in sources-communications, revealing communicative meaningful codes in the systems (subsystems) and in their responses to each other and to the outside world.

Another part of Luhmann's theory, namely, the concept of systems differentiation of society, plays an essential role when studying the history of mankind and the differences in the development of various cultural and civilization regions. There are four forms of such differentiation according to it. They "accumulated" consequently during the entire human history, and today they are often united with each other in various parts of the world in a very particular way.

\section{Four Forms of Systems Differentiation of Society}

The first form among them has been the segmental form of a systems differentiation. It appeared at the dawn of the history of mankind, when various groups of people, although having sporadic communicative relations among themselves within the entire planet (Luhmann insisted that human society as a universal social system is possible only in the form of a world society. Here he totally disagreed with his teacher T. Parsons who wrote about "the system of modern societies"3), but any intense integrating communications were taking place only inside the local segmental communities - communes and tribes. Actually, they could not be broader, considering that oral communication among someone directly present was the only way of communication, and in the period prior to the "Neolithic revolution", the primary crowd and early family

\footnotetext{
${ }^{3}$ Парсонс Т. Система современных обществ / пер. с англ. Л. А. Седова и А. Д. Ковалева ; под ред. М. С. Ковалевой. М. : Аспект Пресс, 1998. 270 с.
} 
communes generally survived due to rather isolated living in large, but separate territories suitable for hunting. We know this kind of a social order well from Marxist historical scheme as a primitive early human order.

A new form of a systems differentiation has emerged when a powerful integrating "center" has grown among many separate segmental communities. Its emergence is possible primarily because there is a new means of communication, namely, written language. Thanks to it, communication goes beyond communications among someone directly present and extends over long distances in space and time. At these distances, identical (or approximately identical) meanings of communications are established, and hence - the meanings of actions, events, social orders, structures of expectations, and thoughts, mental structures of the population masses as well, since the systems of their participants' consciousness are also "connected" to communications. Such a supreme order of social life, in conjunction with its certain sociocultural unification, indicates the emergence of nothing else but civilization.

It is known that civilization is characterized by the presence of not only written language, but also other attributes. They include, in particular, the state, cities as centers of attraction for a colorful rural district, monumental buildings (made of stone or burned brick) as material symbols of stability and historical succession, and a developed social structure (at least, the division into "those who fight, those who pray, and those who work"). These elements do not appear simultaneously, but can be formed for many and many centuries, but a new type of social organization is fixed with the emergence of written language. Due to it, reputable texts are created and distributed - first of all sacred ones, but in combination with them and with references to them - the powerful, administrative texts as well. The texts of local, functional or individual content appear later on.

The center itself, producing reputable texts, acts as an organizational and unifying core in all important functional fields of social life. Among the most important ones are the religious, political (power-administrative), economic (economic-fiscal), artistic, scientific (search of truth), etc. Such a multifunctional religious-power-property center regulates and directs the daily life activity of these segmental social communities (rural and urban), 
which must be multifunctional as well. These peripheral communities maintain also their own traditions, which should be taken into account by the center, and, finally, regulate the life and behavior of individuals, bring together their interests and, as usual, act as collective counterparts in communicating with the center.

Not only one such systems-forming civilization center can be formed in the world. Luhmann himself calls civilizations as "high cultures" and counts in the history of mankind (obviously, following A. J. Toynbee) "from 20 to 30 " such local societies. It goes without saying, that here he includes societies with a center-peripheral form of a systems differentiation.

To their number he includes societies with a third, stratifying form of a systems differentiation as well. The latter is the division of society into communicative relatively closed social groups - strata located at different steps of the hierarchical ladder ("rank order", according to Luhmann"). As usual, it complements (namely, complicates) the structure of a society with a division into a center and periphery at a higher level of its development. It may be a caste hierarchy in India, as well as a ranking bureaucratic hierarchy in China, or a class hierarchy in medieval Europe. Luhmann writes about such a complex structure, when the general centerperipheral systems differentiation is combined with segmental differentiation in the village and stratification differentiation in the city. In any case, it is all society of "high cultures", or civilization.

We define civilization as "a set of interrelated and mutually agreed spiritual, moral, political, economic and social means (media), through which society as a system of communications provides its functioning and stability in space and time"5. However, if we always deal with communications here, which as we have already known, are structurally similar, and their systems are functionally similar, then how can we distinguish between existing civilizations and, at the same time, describe the differences that have been their features for centuries or millennia? To that end, we can not rely on the meanings of communications, because they are always certain and narrowly directed, and we use the category "style of communications", which means a kind of deviation, orientation,

\footnotetext{
${ }^{4}$ Луман Н. Дифференциация / пер. с нем. Б. Скуратова. М. : Логос, 2006. С. 101.

${ }^{5}$ Космина В. Г. Проблеми методології цивілізаційного аналізу історичного процесу : монографія. Запоріжжя : Запорізький національний університет, 2011. С. 127.
} 
manner of communications, the way of organizing their external forms, inherent in one or another civilization ${ }^{6}$.

According to externally expressed style of communications, we can distinguish and describe such modern civilizations as Indian, Chinese, Japanese, Islamic, belonging to the Eastern "branch" of civilizations, as well as Western, Latin American, and Eurasian, which are conventionally united into the Western "branch". A specific study of the historical development of each of them should take place by analyzing the evolution of meaningful relations between communications, their sequences, subsystems and systems.

It is worth reminding that the emergence of civilizations enabled the emergence of a new means of communication - the written language. However, the spread of one of other means of communication, namely, book-printing, predetermined not less "revolutionary" systemic changes, at least in one of the civilizations during the 15-16th centuries. The transition of the Western European society to the fourth form of systems differentiation is exactly associated with it, namely, the division into functional social systems of politics, law, economics, production, science, intimate relationship, art, education, health care, religion, morals, etc. that, actually, meant the beginning of the movement to the post-civilization.

It is noteworthy that the book-printing did not cause such changes in other civilizations, even in China, where, after all, it had appeared much earlier. The reasons are obviously hidden in the specific organization and specific conditions of the existence of the Western European medieval society. Although, it is generally referred to the traditional societies, it significantly differed from the latter, in particular from the Eastern ones, in a number of features.

We can start with the fact that in that civilization, along with a feudal agrarian society, which could largely resemble the traditional oriental societies; there were cities, being, in fact, civilization successions of ancient policies. The latter represented a unique structure for the ancient world. If in the civilizations of the East of that age the patrimonial state (where the principle of "power-property" is dominated) co-existed and interacted with community subordinate to it, then in the ancient Greece, these institutions, in fact, merged into one institute, namely, the state-

\footnotetext{
${ }^{6}$ Космина В. Г. Проблеми методології цивілізаційного аналізу історичного процесу : монографія. Запоріжжя : Запорізький національний університет, 2011. С. 131.
} 
community, or the polis. The polis retained all attributes of the community, including communal property (joint property) on the land and meetings of community members (heads of families). However, at the same time, it became a state where the meeting of community members-citizens gained the status of the highest authority, and the land plots were in double ownership - they belonged to the polis and the citizen who owned the household (oikos). It resulted in unprecedented political and economic sovereignty of the personality. This polis tradition was, to a greater or lesser extent, maintained (or reproduced) in many medieval cities, which were largely autonomous centers of trade and commerce, and where the key issues of their inner life and communication with the outside world were solved collectively within the framework of the universitas (urban communes, guilds, shops, brotherhoods, universities, schools, etc.). By comparison: in the East cities remained primarily the centers of the state administration, the rank of which determined the status of the city.

However, not only the presence of such cities determined the specifics of the European Middle Ages on the ashes of other, non-Western societies. Here, the integrated multifunctional religious-power-property center had never been formed, although some tendencies towards its formation on the basis of hierarchical agrarian society were observed. There were several reasons. Firstly, there was no unification between religious and temporal power. If the first one was concentrated in the hands of the head of the Catholic Church - the Pope; then various temporal rulers executed the second one in their possessions - kings, princes, electorates, etc., who often competed for the superiority of their power with the Pope and his representatives at the local level.

Secondly, there was no somebody's monopoly disposal of property for any resources, and primarily for the main one - for land. This property was also distributed between the church, the royal power, the ancient aristocracy, servants of the nobility (conditional property), and others. Thirdly, the natural climatic conditions themselves in Europe did not require any organizational intervention of the state in production processes (such as the construction of irrigation systems or the terracing of mountain slopes in the East). And fourthly, the latter did not require the collective work of commune members and consolidation of the peasant community as a universal multifunctional peripheral structure, which would bring together the interests of commune members, limit their 
individual contacts with the state and make the state unsubordinated to society, patrimonial.

It should be added that the power-administrative structure in the Medieval European society did not have a clear organization, since it was based on a rather complex and intricate system of contractual vassalseignior relations with the mutual obligations of the seignior and the vassal.

And most importantly, the Christian faith requires a person, who has come to the path of salvation for the sake of restoring the lost (due to original sin), to be godlike in their thoughts and actions always to be likened to Jesus Christ. This, in particular, means - to realize, comprehend, evaluate and re-evaluate almost every life step, comparing it with the ideal. This is the burden of the responsible personal freedom of Christians who focus on their own actions and thoughts, and create the objective preconditions for the formation of individualistic features in their character and mentality traced in the very idea of the individual connections of a person with God.

All these circumstances resulted in the relative spiritual, social, political and economic independence of the individual, even in a feudal society (of course, in comparison with the Eastern societies), not mentioning the cities, as well as the noticeable communicative influence of the individual on the life of society. The result was a fair amount of flexibility in responding of various segments of Western society to changes in the outside world, and hence its ability to internal systems transformations.

\section{Circumstances of the Western Society Transition to Functional Form of Systems Differentiation}

To begin with, the material and technological preconditions for systems transformation should be outlined. First of all, we should note the above mentioned optimal climatic conditions of Western Europe (the peninsula location near the warm current of the Gulf Stream, relatively warm and short winter and "long" summer, the optimal amount of precipitation, sufficiently fertile soils), which, on the one hand, stimulated actively the development of agrarian production, and on the other hand it made it quite effective. It was supplemented by innovations in agrarian production at the turn of the I - II B.C. (transition to three-field and multi- 
field systems, wide use of organic fertilizers due to the development of livestock, the use of an iron plough, water mill, etc.), which increased fruitfulness and created some surplus of agricultural products. It was resulted in the development of trade in agricultural products in cities and the growth of cities and urban craftsmanship.

The emergence of a mechanical clock and rationalization of craft production on the basis of time (and its reducing!) required for the implementation of certain industrial operations, the introduction of specialization and co-operation of labor, the emergence of manufactories on this basis and the growth of manufacturing commodity production were of great significance. The emergence of gunpowder caused a real revolution in military affairs and military-industrial production, and the emergence of the compass was a revolution in navigation and, Great geographical discoveries, which, in particular, provided a flow of gold from America, served as the primary accumulation of capital in European countries).

The success in the production field and the economic field development began to give them the nature of independent values in human lives engaged in them directly, and in the life of the entire society, contributed to the gradual differentiation of these social systems.

The second group of preconditions was socio-political. Growth of the Western European cities (it should be reminded that they were original civilization successions of antique polis) was primarily due to the development of urban crafts (in some time - manufactory commodity production) and trade. Therefore, for their further development and even maintenance of their own existence, they required external security (primarily from the arbitrariness of local and neighboring large feudal landlords), expansion of markets for goods produced in cities, and most of all - overcoming obstacles to their transportation - various inter-feudal barriers, borders, customs, etc., which the same feudal landlords set along their possession. Only strong royal power could provide such protection and free market.

From its part, the royal power itself strived for independence and overcoming the actual dependence on the noble vassals (the same feudal lords) who made up its military and administrative power, but increasingly behaved in accordance with their own interests. It required creating its own military forces, an administrative, judicial and fiscal 
system, which needed new and stable sources of funding. Fast-growing cities, urban production and trade, could be such source, but only under the condition of their further development and observance of certain limits in taxation by the state authorities, so that this development and enrichment of cities continued.

A certain compromise between royal power and cities allowed for the emergence and prolonged existence of an absolute monarchy in the European countries which was unlimited centralized state power of the king. Freedoms (or arbitrariness) of noble feudal lords was limited, interfeudal borders were destroyed (a single national market was opened), central state institutions were strengthened. Interested in the further growth of financial revenues, the absolute monarchy itself contributed to the development of production (including manufactory) and trade, establishing the general "rules of the game", acceptable and common for the cities, and giving the cities the right to organize domestic life on the basis of self-government (for example, "Magdeburg Law").

It was leading to the fact that the whole country was the "field of activity" for various groups, the borders of the former universitas gradually erased. Striving for success in their activities governed a professional interest in a specific social field. And within its limits, certain meanings and styles of social communications were developed. Thus, the formation and functioning of absolutist political regimes, which no longer relied on the system of personal relationship among the nobility, required the development of a special art of politics, which in a difficult organized society should be carried out by the monarch and his authorized representatives. One of the consequences was the widespread public distribution of N. Machiavelli's treatise "The Prince". The foundations for the next separation of social systems of politics and law in social communications were laid.

Of course, the state acquisition of sovereignty, and first of all, independence from the church, as well as the differentiation of other functional systems would certainly have been impossible if there were no changes in the spiritual area at the same time. Therefore, the spiritual preconditions of system transformation were of great importance. The growth of the material well-being of individuals, and hence their independence, the development of cities and the growth of their influence, long history of "Crusades" and familiarity with foreign cultures (the Great 
geographical discoveries and overseas conquests had the same consequences later on) contributed to the rise of value of the mortal life of Christians. In the system of medieval communications there was a change in the very position of human observation. It had been the position of the Gospel doctrine earlier. An ordinary person was considered a priori sinful and neglected, but only a special person - "a holy person" - could be depicted and respected. Now it has been the position of observation of the person themselves and their external world, including both God and the Gospel doctrine.

In European history under such conditions the cultural-historical process arose and deepened in the 15th-17th centuries, known as the Renaissance, namely, the revival of, first of all, ancient humanist traditions, respecting for and honoring a person. However, these cultural traditions were already revived on a fundamentally new, Christian ground. Artists, sculptors, poets, writers, musicians, scholars began to show extraordinary interest in a person, their mortal everyday life, their aspirations and preferences. Celebration of a real person was interpreted as the glorification of God-creator and church as the comprehension of divine craft.

The Renaissance with its values of humanism and individualism played an outstanding role in the fact that art also began to turn into a separate system of communications (a social system) with a common meaningful code such as "the beautiful".

If the Renaissance was the achievement of only rich and educated elite of society, then, new cultural values could only come to the public masses in an acceptable and understandable religious form. The decisive role here was played by the Reformation in the Christian church and the emergence of Protestantism in the form of Lutheranism and Calvinism. The first efforts at reforming the Catholic Church took place in the 15th century, but German priest Martin Luther made the most decisive step in 1517, speaking with 95 theses against the sale of indulgences. He denied the ability of the church to influence the destiny of a person (their soul) after death, and stated that a person can justify themselves before God through their belief, which is God's grace itself, and therefore the church can not be a mediator. He translated the Bible into German language so that every person could compare their actions with the Holy Scriptures. After the church tried to excommunicate Luther, German princes 
protested against its actions, which led to the new movement called Protestantism. The essence of Luther's (Lutheranism) doctrine: human actions are justified, if dictated by their unselfish belief in God. It meant that a person could determine their way of life according to the belief.

Calvinism (Geneva Archbishop Jean Calvin's teachings) was the next, more radical step in the Reformation. The essence of Calvinism is in the idea of an absolute predetermination of the final destiny of a person: God has determined his decision on this person in the Last Judgment yet before their birth, and a person can not change anything, no matter what they do, and nothing can be changed by the church as well. According to logic, it would have to undermine all human life and social activity. On the contrary, the opposite things happened: the Protestant-Calvinists began to demonstrate extremely high labor and entrepreneurial activity, striving for continual success in mortal life. They completely limited their own consumption, and all incomes invested in new production. It was the activity of Protestants that laid the spiritual, and, to a large extent, the mental foundations of European capitalism. Why? A believer wants to know their final destiny more than anything else, if it has been already defined, and therefore, they seek evidences of their choice for salvation at the Last Judgment in everything that happens. They believe that the righteousness and impeccability of they life, the success in their activities, to which, apparently, the God has appointed them, serve as evidences of the choice for salvation by themselves. It stimulated entrepreneurship, the labour activity of Protestants. If the Protestant succeeded, then in their eyes, and in the eyes of people around them, they appeared to be God's chosen. In this case, success could not be a one-time thing, it should be constant and daily, and therefore, having earned any money, they invested it in a new production. This fact extremely rationalized the life and activities of the believer.

A fundamentally new situation arose, when religion as an integral part of a multifunctional center, "the bearer of truth", a universal regulator of morality, and hence communications in all fields of social life, turned, as well as morality, into one of the systems of communications (social systems).

The ways for the independent formation of out-differentiated communicative systems around their own meaningful codes were discovered. It also concerned politics, science and art, and above all, 
economics. Therefore, in order for individual media of social communications began to turn into self-referential autopoietic social systems within the entire Western European society, already in the 16th century the material, technical, political, economic, and most importantly - spiritual preconditions practically formed in the Western civilization, previously controlled by religion and morality. It was only necessary that the relevant communications went beyond interactions direct, usually oral, communication within the universitas - and linked numerous communications of a certain orientation, scattered in space and time in a unified system.

The book-printing created such conditions. It appeared in Europe after the invention of a printing machine by J. Guttenberg in the 15 th century. By the end of the 15th century they reached many millions of copies. In the 16th century the volume of book printing increased by 20 times; and in the 17th and 18th century it increased by another 5-6 times ${ }^{7}$. At the same time, a great share of publications consisted of biblical texts that were published by Protestants. Protestantism expanded rapidly due to the book-printing. Large publications of books were published by the Catholic Church. Books on the issue of science, philosophy, politics, law, economics, etc., were published in smaller volumes in circulation of several hundreds or thousands of copies, but significant for that time; works of fiction were published even more. They formed the information field in certain areas, the meanings and standards (styles) of behavior of readers, their culture. As a result, according to W. McNeill, instead of one, more or less unified corpus of reputable texts that defined the meaning of human life, there were many book traditions: "Lawyers, doctors, theologians, mathematicians, scientists, writers and other specialists produced their own views of life, and their less and less worried about the issue of how their professional activities correspond to some general understanding of the world" 8 .

\section{Functional Systems: from the Early Modern Time to the Present}

Therefore, starting from the 16th century in the West, the formation of the out-differentiated functional systems had already occurred. This

\footnotetext{
7 Шоню П. Цивилизация классической Европы / пер. с фр. и послесл. В. Бабинцева. Екатеринбург : У-Фактория, 2005. С. 320.

${ }^{8}$ Мак-Нил У. Цивилизация, цивилизации и мировая система. Цивилизациии : вылnуск 2. М. : Наука, 1993. C. 22.
} 
process lasted for several centuries. Each of the systems developed, observing the development and changes in its environment, especially in other functional systems. It can be said that such social systems finally obtained their "personal look" (personal external style forms) in 19th century. Their outlines are sufficiently described in the scientific literature, mainly from the positions of external observation. Therefore, here we note their general features only.

In politics, as a result of revolutions or the permission for at least part of social groups to take part in the state regulation, the democratic principles of the political system have gradually established, namely: the electorate of power; separation of powers between the three branches (executive, legislative, judicial); wide (and in the 20th century - general) elective right; competition of political parties as representatives of interests of various social groups; the establishment, finally, of a civil society capable of solving social problems without the participation of the state, based on mutual relations of the individuals themselves or their associations alone.

At the same time, the legal system as a set of legal norms, institutes and branches of law gained its own development. In the Western civilization, it was divided into two types: Romano-Germanic, in which the main sources of law are legislative acts, and Anglo-Saxon, where along with such acts there are sources of judicial precedents. The culmination of law-making was the adoption of Constitutions that regulate the functioning of power itself.

In the economy, evolution revealed in the legislative approval of private property, in the development of the market and banking system, creation of share capital (the 20th century), deepening of the competitive struggle, and domination of hired labor of freelance workers. The main economic "classes" were entrepreneurs, hired workers and a large middle class. Influential social groups were also employees, including state employees, small entrepreneurs, persons of free occupations, managers, some peasants, etc.

In the production field, the accelerated development of industrial technologies resulted in the creation of various types of machines that replaced manual labor, and manufactories that combined specialization and co-operation of labor, and then it resulted into the establishment of a 
large machine production, which technical and organizational level was constantly increasing.

There was an intensive development of science focused on searching the truth. It is worth reminding that the science search for truth was inherited from religion, however, through a range of stages. At each stage people saw the truth in different ways. In the culture of the Middle Ages: only God knows the truth, the church can approach it; in the culture of the Renaissance: everyone's opinion is true; in Protestantism: only something in what I believe is true; finally, in modern European science: the truth is what can be proven. At the philosophical level an important role in the differentiation of science from religion was played by Rene Descartes' teaching of two substances created by God: the "physical" in which the Creator laid laws of structure and movement, and "spiritual", which does not have a definite structure and location, and the proof of its existence is the famous "cogito ergo sum" - "I'm thinking, so I'm existing". Orientation to the study of the first substance by the second one in order to comprehend the greatness of the Creator, gave impulse to the unprecedented development of natural sciences, and later - to the sciences of society, which began to comprehend the meaning of the functional social systems themselves.

However, even earlier the art began to realize and display human life and society, which became more and more complicated, by their own means. Perhaps, this was reflected in the Baroque style in the most demonstrative way (in the 17th century), in its striving to embrace the inner complexity and contradictory nature of the world in a certain form of unity while at the same time aspiring to something new, to the future. Baroque was characterized by irrationalism and disharmony of world perception, fear of the outside world, refusal from anthropocentrism of the Renaissance and the development of landscape and still life, namely, genres "without a person". The comprehension of the diversity of the outside world resulted in the multiplicity of forms and genres of art and literature: versatility in architecture, symphony in music, novel in literature, etc.

The rest of the functional systems such as education, health care were formed in the same way. Influential organization systems along with interactive systems, operated practically in all of them. It meant, by the way, that the old Christian morally loaded conception with its code of distinction of "respect/disrespect", "good /evil" was not suitable for 
describing the self-referential functional systems evolution directed to the unknown future.

Moreover, the clearly defined social hierarchy disappeared now, crowned with a multifunctional center, and hence the civilization structure itself. Their place was occupied by post-civilization with a "heteroarchaic" structure of society. However, along with this, the individual lost the former apparent social identity, giving them belonging to multifunctional segmental communities, where almost all their communications take place - communities, universitas, and so on. With the disappearance of the latter and the transition to functional social systems, they could not, in all they individuality (individuo "inseparable"), be identified with none of the system. These systems are completely indifferent to each particular individual; individuals are left to themselves and now clearly remain outside of social systems.

Thus, with assertion of the Western society differentiation in functional systems, some new semantics was required to define a new state of society and a new status of a personality. It was supposed to lay the foundations for the structures of meaningful expectations in social communications, which in the traditional civilizations was carried out mainly by religion. However, in a secular society, this could not be done by religion anymore, but the time for the semantics of out-differentiated systems had not come yet. Therefore, a so-called "intercepting" or "transient" semantics arose (according to N. Lumann) $)^{9}$ in the form of liberal ideology. It was formed on the basis of philosophical understanding of reality and it was distributed in the society as communication, in particular, through the system of education (with the support of authorities), popular literature, press, etc.

Liberal views on a person and their life in the society are based, first of all, on the ideas of personality freedom and social agreement, deprived from religious colouring. The concept of a social agreement creates the theoretical basis for the development and adoption of the constitution of the country (written equivalent of a social agreement), the formation of a law-governed state. Such interpretation of a social agreement is used even today: the state and the power must serve the interests of people themselves.

9 Луман Н. Самоописания / пер. с нем. А. Антоновского, Б. Скуратова, К. Тимофеевой. М. : Логос, ИТДГК «Гнозис», 2009. С. 226. 
Along with liberalism, other ideologies with "intercepting semantics" appeared, strongly opposed to the differentiation of society into functional systems. It is nationalism that relied on the semantics of a segmental society, and socialism (Marxism), that focused on the semantics of a stratified ("class") society. However, by the end of the 20th century both ideologies, especially in their extreme forms, have lost their former influence.

In the 20th century, the functional social systems continued to evolve on the basis of autopoiesis (self-creation) on their own meaningful codes and self-reference (appeal to themselves). The speed and frequency of communications was increasing, which made the systems often fail to respond in time to their own changes in the world around them. In the 21 th century, domination of electronic media of the communications distribution ensures their high intensity exactly on a world-wide basis, but within the framework of the same functional systems. Now they have become world-famous and decisive for mankind.

The modern stage of the evolution of the world community takes place under the sign of globalization, which is interpreted by scientists, mainly, as an increase in the interdependence of countries and regions, and is associated primarily with the completely visible process of forming a single, global economy. At the same time, great attention is paid to other aspects of globalization - political, cultural, social, informational, environmental, safety, etc.

However, its complexity is in the fact that non-Western civilizations are continuing to exist, which preserve a number of their traditional features. Now they have to interact not with other similar civilizations, but with post-civilization functional world communication systems that have their own meaningful codes and have originated from out-differentiated functional social systems of the Western civilization.

W. McNeill writes as to the latter, that even in the 17 th century in Europe, the destruction of the ancient Latin-Christian tradition took place as a result of the process of human interaction, which "is gaining strength and importance as transport and communication systems are improving". Therefore, "about three and a half centuries ago, European civilization disappeared, giving the way to the global cosmopolitanism that arose at that time and exists at present." Today, "the communications system has become global and flash-like in speed. Information having a general 
nature, now, as a rule, brings specialists in a particular field together, overcoming linguistic and political barriers"

The orientation and speed of autopoiesis of these self-referential systems are usually correlated with the events in their environment. Their evolution takes place in the most dynamic, effective and balanced way, where they have formed simultaneously and when they worked in close interaction for several centuries, that is, in the West. Thus, the social system of economy can generate intensively all new operations (communications of sales and purchase), if the operations of the production system are updated in the same intensive degree (the production of up-to-date products in large quantities). For the success of the latter, it is required to upgrade technologies continuously, and to that end - in the chain - all new design developments are necessary as well as applied and fundamental research, training of relevant specialists, changes in information networks, in art, etc. A legal system, a democratized system of policy, a flexible fiscal system must promptly react to all these processes accordingly, and, again, by circle, a system of economics that provides appropriate financial revenues. In each of these systems and subsystems, the tone is set not by interactive systems, but by systems of organization, some of which are already global in nature, such as transnational corporations and multinational banks. Moreover, according to N. Luhmann, organizations from different systems, in contrast to the most functional systems, can interact directly with each other; the World Economic Forum in Davos is an example of it.

However, functional communication systems spread around the world at different speed. The most "successful" is the economic system. It is exactly because trade (exchange), including for long distances, has the longest history and has always been a channel of interaction between countries and civilizations, subordinating even wars between them. And in today's interconnected world, economic communications have only incredibly accelerated, resulting in the creation of an appropriate infrastructure.

However, production and production technologies spread more slowly, saying nothing of communicative systems of science, education, law, and politics. One of the main reasons is not readiness of out-

10 Мак-Нил У. Цивилизация, цивилизации и мировая система. Цивилизациии : вылускк 2. М. : Наука, 1993. С. 22-23. 
differentiated (or weakly differentiated) for functional systems of societies in all its range to connect to the corresponding communication systems, and thus to achieve their coherent and effective functioning. It creates imbalances in the processes of globalization, exacerbates social, economic, political, cultural, environmental problems in non-Western societies and nourishes anti-global, anti-Western, "anti-imperialist", fundamentalist movements. In some cases, international terrorism also arises on this ground.

At the same time, in a number of countries and civilizations, it was possible to combine their own civilization traditions with the logic of the world evolution of functional systems and they benefited from the advantages of globalization, although in other roles. In this sense, Ukraine has a number of preconditions in the cultural and civilization context in order to be successfully involved in the specified world systems as well. In general, globalization encounters the more or less stable civilization structures almost everywhere that continue determining the meaning and lifestyle of the public masses and, at least, can not be ignored.

\section{CONCLUSIONS}

The theory of German sociologist Niklas Luhmann interpreting the society solely as a system of communications, allows us to study the history of civilizations in the perspective of changes in the forms of system differentiation of the relevant societies. At different stage of mankind, four such forms appeared which could co-exist and they are: segmental, central/peripheral, stratification and functional.

The Western European society was functioning as a classical civilization in the Middle Ages ("the society of high culture") with division into the center and periphery and elements of stratification, although it had a range of peculiarities, in particular, split nature of multifunction religious- power center and even a certain competition between religious and temporal power. However, certain media of communications, well-known since antiquity, separated and transferred to the independent functional systems such as politics, law, economy, production, science, intimate relationship, art, education, safety, health care, religion, morality etc. with the emergence of such means of communication as book-printing and its rapid expansion in 15th century. 
Finally, re-orientation of social interests and values from the past, from the tradition to the future took place on the turn of 18th-19th centuries. Nowadays, they have become global in their essence, and the Western civilization has turned out a post-civilization. Although, non-Western civilizations, in general, have still kept their identity, resulting in the tension between their universal moral-religious meaningful codes and meaningful codes of communications of functional systems, it should be noted that all developed countries have gained their success because of the very active inclusion in this systems.

\section{SUMMARY}

The article deals with the issue of meaning and historical origins of the Western modern society as well as its uniqueness. The author relies on the systematic and communicative theory of Niklas Luhmann, namely, on his theory of differentiation. The following historical forms of systems differentiation of society are considered: segmental, center/peripheral, stratifying, functional.

In the Middle Ages European society belonged to the classical civilizations, where the center/peripheral and stratification forms of systemic differentiation ruled, organizing society not in a very strict way. It is the relative amorphous nature that allowed these societies to succeed in responding to the challenges of the outside world. As a result, after the emergence of such means of communication as a book-printing, a transition to a new form of systems differentiation - division into autonomous functional systems of politics, law, economy, production, science, intimate relationships, art, education, health, religion, and morality became possible. This unique transformation has dramatically accelerated the development of the West and ensured its domination in the world up to the present time.

\section{REFERENCES}

1. Luhmann N. Soziale Systeme. Grundriss einer allgemeinen Theorie /Niklas Luhmann. Frankfurt am Main : Suhrkamp Verlag, 1984. $674 \mathrm{~S}$.

2. Luhmann N. Die Gesellschaft der Gesellschaft / Niklas Luhmann. Frankfurt am Main: Suhrkamp Verlag, 1997. 1150 S. 
3. Парсонс Т. Система современных обществ / пер. с англ. Л. А. Седова и А. Д. Ковалева ; под ред. М. С. Ковалевой. М.: Аспект Пресс, 1998. 270 с.

4. Луман Н. Дифференциация / пер. с нем. Б. Скуратова. М.: Логос, 2006. С. 101.

5. Космина В. Г. Проблеми методології цивілізаційного аналізу історичного процесу : монографія. Запоріжжя : Запорізький національний університет, 2011. С. 127, 131.

6. Шоню П. Цивилизация классической Европы / пер. с фр. и послесл. В. Бабинцева. Екатеринбург : У-Фактория, 2005. С. 320.

7. Мак-Нил У. Цивилизация, цивилизации и мировая система. Цивилизащии : выпууск 2. М. : Наука, 1993. С. 22, 23.

8. Луман Н. Самоописания / пер. с нем. А. Антоновского, Б. Скуратова, К. Тимофеевой. М. : Логос, ИТДГК «Гнозис», 2009. C. 226.

Information about the author: Kosmyna V. G. Doctor of Historical Sciences, Assistant Professor at the Department of Philosophy and History Educational and Scientific Humanitarian Institute of V. I. Vernadsky Taurida National University, 33, Ivana Kudri str., Kyiv, Ukraine. 